J. MED. MICROBIOL.-VOL. 16 (1983), 323-331

(C) 1983 The Pathological Society of Great Britain and Ireland

\title{
THE PURIFICATION, STRUCTURE AND SYNTHESIS OF PROTICINE 3
}

\author{
B. W. SENIOR \\ Department of Bacteriology, The University of Dundee Medical School, \\ Ninewells Hospital, Dundee DD1 9SY
}

\begin{abstract}
Summary. The ability of Proteus mirabilis to produce the bacteriocin, proticine 3 , is found almost exclusively in strains that cause severe infections of the upper urinary tract. Proticine 3 was purified from lysates of mitomycin $\mathrm{C}$-induced cultures. Biological activity was associated with structures resembling bacteriophage tails which, when first produced, were in the form of "nails" with one pointed end and a base plate with appendages at the other end. This form was unstable and changed to a "rocket" form in which the outer sheath contracted and thickened to reveal a protruding, hollow core that often became detached from the sheath. Purified proticine 3 comprises two major and nine minor proteins. Fluorography showed that during production of the proticine, a $58000 \mathrm{~mol}$. wt protein was synthesized late in the induction process and became the most intensely labelled protein in the culture. Synthesis of this protein coincided with the appearance and increase in titre of biologically-active proticine within the cell and with the appearance of "nail" forms. The protein is believed to be shed when an active "nail" is converted to an inactive "rocket" and to be either the component of proticine 3 associated with its lethal activity, or the protein required for the correct assembly of the constituent components into a biologically-active particle. The role of proticine 3 as a virulence factor is discussed.
\end{abstract}

\section{INTRODUCTION}

Proteus mirabilis is the second commonest cause, after Escherichia coli, of urinary-tract infections. The virulence mechanisms of the two organisms are thought to be quite different. Most $E$. coli infections are self-limiting and confined to the bladder whereas $P$. mirabilis infections tend to persist, particularly in the upper urinary tract where they cause much greater damage and often bring about the formation of renal stones (Braude, Shapiro and Siemienski, 1959; Braude and Siemienski, 1960; Fairley et al., 1971; Griffith, Musher and Campbell, 1973).

Urease is thought to play a major role as a virulence factor in Proteus urinary-tract infections (Braude and Siemienski, 1960; Musher et al., 1975; Senior, Bradford and

Received 5 Oct. 1982; accepted 13 Dec. 1982. 
Simpson, 1980) although fimbriae (Silverblatt, 1974) and other factors (Eudy, Burrous and Sigler, 1971) may also be involved. Certain $P$. mirabilis strains appear to have a special affinity for the urinary tract (Senior, 1979). The strains that are associated with severe and persistent infections of the upper urinary tract produce, almost without exception, the bacteriocin, proticine 3. Strains that do not produce this bacteriocin or that form different proticines are seldom associated with upper urinary tract infections (Senior, 1979).

The aim of this study was to investigate the characteristics of proticine 3 in order that its role as a virulence factor in $P$. mirabilis urinary-tract infections might be assessed.

\section{MATERIALS AND METHODS}

Bacterial strains. P. mirabilis CW977, the standard proticine-3-producing strain, and $P$. mirabilis CW712, the specific sensitive indicator strain for proticine 3 (Senior, 1977), were maintained as pure cultures on nutrient-agar slopes at $4^{\circ} \mathrm{C}$.

Culture media. The medium used for proticine-3 production was either PP3 mediumProteose Peptone No. 3 (Difco) $10 \mathrm{~g}$ and $\mathrm{NaCl} 5 \mathrm{~g}$ in distilled water $1 \mathrm{~g} \mathrm{~L}$-or GSYE medium - minimal salts medium (Grabow and Smit, 1967) supplemented with Yeast Extract (Oxoid L21) $50 \mathrm{mg} / \mathrm{L}$.

Proticine 3 production was induced by adding mitomycin C $1 \mu \mathrm{g} / \mathrm{ml}$ to $P$. mirabilis CW977 growing exponentially in PP3 medium in an orbital incubator at $30^{\circ} \mathrm{C}$ in the dark. Incubation was continued until the cells lysed. Cell debris was removed from the culture by centrifugation at $10000 \mathrm{~g}$ for $5 \mathrm{~min}$ at $4^{\circ} \mathrm{C}$. The clear supernate containing proticine 3 was removed, gently mixed with a few drops of chloroform and stored at $4^{\circ} \mathrm{C}$.

Proticine 3 purification. Proticine 3 activity was concentrated from mitomycin $\mathrm{C}$-induced culture supernates by centrifugation at $100000 \mathrm{~g}$ for $2 \mathrm{~h}$ at $4^{\circ} \mathrm{C}$. The pellet of crude proticine was resuspended in a small volume of $5 \mathrm{mM}$ Tris buffer $(p \mathrm{H} \mathrm{7.2)}$ and purified by repeated banding on sucrose gradients; $20 \mathrm{ml}$ gradients of sucrose $15-40 \%(\mathrm{w} / \mathrm{v})$ in $5 \mathrm{~mm}$ Tris buffer were centrifuged unbraked at $40000 \mathrm{~g}$ for $3.5 \mathrm{~h}$ at $4^{\circ} \mathrm{C}$. Purified proticine formed a band about one third of the way down the gradient at a sucrose concentration of $c .22 \%(w / v)$. This band was isolated, diluted in an excess of $5 \mathrm{~mm}$ Tris buffer, and centrifuged at $100000 \mathrm{~g}$ for $2 \mathrm{~h}$ at $4^{\circ} \mathrm{C}$; the deposit was suspended in a small volume of buffer and stored at $4^{\circ} \mathrm{C}$.

Labelling the protein components of proticine 3. Mitomycin C $1 \mu \mathrm{g} / \mathrm{ml}$ was added to an exponentially-growing culture $\left(\mathrm{E}_{550}=0.25\right)$ of $P$. mirabilis $\mathrm{CW} 977$ in GSYE medium at $30^{\circ} \mathrm{C}$. At this point and at 15 -min intervals throughout a $3 \mathrm{~h}$ induction period, $100 \mu \mathrm{l}$ portions of culture were removed and labelled with $2 \mu \mathrm{Ci} 4,5-{ }^{3} \mathrm{H}$ leucine for $15 \mathrm{~min}$ at $30^{\circ} \mathrm{C}$. Further incorporation of the isotope was stopped immediately by adding $100 \mu \mathrm{l}$ of disruption buffer $(0.05 \mathrm{M}$ Tris- $\mathrm{HCl} p \mathrm{H} 6.7$ containing SDS 5\%(w/v), glycerol $20 \%(\mathrm{w} / \mathrm{v}), 6 \mathrm{M}$ urea, 2 -mercaptoethanol $1 \%(\mathrm{v} / \mathrm{v})$ and a trace of bromophenol blue dye) and boiling the mixture for $2 \mathrm{~min}$. The samples were stored at $-20^{\circ} \mathrm{C}$ and boiled for 2 min before electrophoresis.

Polyacrylamide gel electrophoresis and fluorography. The protein components of purified proticine 3 were examined by SDS discontinuous polyacrylamide gel electrophoresis (Laemmli, $1970)$ with standard protein markers of mol. wt $(25 \cdot 7-78) \times 10^{3}$. Slabs of acrylamide stacking $4 \%(\mathrm{w} / \mathrm{v})$ over an acrylamide resolving gel $10 \%(\mathrm{w} / \mathrm{v})$ were electrophoresed at $20 \mathrm{~mA} / \mathrm{gel}$ at $4^{\circ} \mathrm{C}$ for $c .3 .5 \mathrm{~h}$. Immediately after electrophoresis, gels were either fixed overnight in glacial acetic acid $10 \%(\mathrm{v} / \mathrm{v})$ in water or stained overnight in Coomassie Brilliant Blue R250 0.1\% (w/v) in isopropanol $25 \%(\mathrm{v} / \mathrm{v})$ and glacial acetic acid $10 \%(\mathrm{v} / \mathrm{v})$ in water, and subsequently destained by gentle washing in several changes of isopropanol $10 \%(\mathrm{v} / \mathrm{v})$ and glacial acetic acid $10 \%(\mathrm{v} / \mathrm{v})$ in water. For fluorography, fixed gels were dehydrated in dimethyl sulphoxide (DMSO) and soaked in a solution of 2, 4-diphenyloxazole 22\% (w/v) in DMSO (Bonner and Laskey, 1974; Laskey and Mills, 1975). The gels were then washed in water, dried under vacuum and exposed to X-ray film at $-70^{\circ} \mathrm{C}$.

Measurement of growth and sonication of cells. Growth was plotted throughout the 
proticine-induction period by measuring the $\mathrm{E}_{550}$ of the culture against a blank of sterile medium with an uninduced culture as a control. At 15-min intervals, 1-ml samples of culture were removed and the cells immediately disrupted by sonication for $1 \mathrm{~min}$ at ice-water temperature. A few drops of chloroform were added to the sonicate. After a brief shake the sonicate was centrifuged for $1 \mathrm{~min}$ at $12000 \mathrm{~g}$ on a microcentrifuge to remove the chloroform and cell debris; the clear sterile supernate was tested for proticine activity and, after staining, examined by electronmicroscopy.

Detection of proticine activity. A 50- $\mu \mathrm{l}$ loopful of the neat or saline-diluted supernate from a chloroform-treated culture of the proticine-3-producer strain or from the sonicate was placed on top of an inoculum of a young culture of the indicator strain that had been streaked across a MacConkey Agar plate. After incubation for a few hours at $37^{\circ} \mathrm{C}$, active proticine preparations had inhibited the growth of the indicator strain.

Electronmicroscopy. Purified proticine 3 was applied to copper grids coated with Formvar and carbon. These were stained with phosphotungstic acid $2 \%(\mathrm{w} / \mathrm{v})$ and examined in a Jeol 100 CX electronmicroscope.

\section{RESULTS}

\section{Proticine 3 structure}

Electronmicroscopy of purified proticine 3 showed the presence of numerous phage tail-like structures (fig. 1). No phage head-like structures were seen. When proticine preparations were examined immediately after the proticine had been formed, most proticine particles were in the shape of "nails" of mean length $1280 \AA$ and width $182 \AA$.

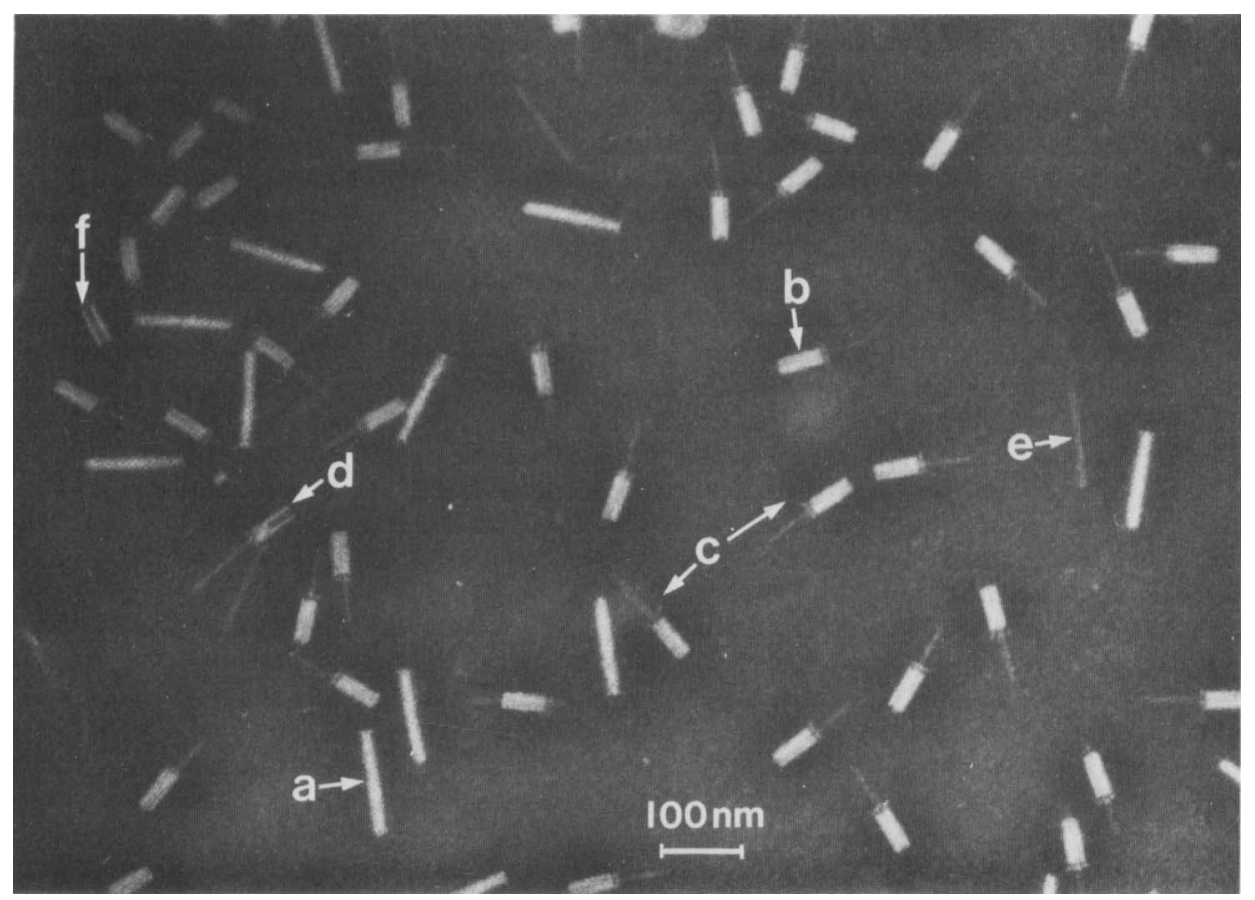

FIG. 1.-Electronmicrograph of purified proticine 3 showing the presence of "nail" forms (a), "rocket" forms (b) and tail fibres (c) attached to the base plate. The hollow core can be seen slipping out from the rocket form (d) and lying free (e) from the empty contracted sheath (f). 
One end was pointed and the other was extended and flat, like a base plate. Occasionally, small pins and longer fibres were seen to be attached to this structure. After storage at $4^{\circ} \mathrm{C}$ for a few days, some of the "nail" forms changed into "rocket" structures in which it appeared that the outer sheath of the "nail" form had contracted and thickened, exposing a hollow core that protruded through the base plate. In the "rocket" form, the core often appeared to be lying to one side within the contracted sheath, suggesting that it was only loosely held in this form. Indeed, the core was often observed to be sliding through the contracted sheath and then to be lying free alongside an empty contracted sheath (fig. 1: d, e, f). The core was the same length as the "nail" form and $68 \AA$ wide.

\section{Proticine 3 composition}

Proticine 3 was purified on numerous occasions from different batches of culture lysates. Polyacrylamide gel electrophoresis revealed the presence of 11 protein bands (fig. 2). Although there was variation in the relative amounts of some of the proteins between different preparations there was no variation in the molecular weights or the number of components. The proteins of mol. wt 49 and $34 \times 10^{3}$ were always major components. The proteins of mol. wt 58 and $40 \times 10^{3}$ were found in variable amounts in different preparations, but the $58 \times 10^{3}$-mol. wt protein was never the major component. The remaining proteins of mol. wt $82,76,47,36,30,28$ and $23 \cdot 5 \times 10^{3}$ only minor components of the purified proticine particles.

\section{Synthesis of the components of proticine 3}

In an attempt to identify the protein component(s) of proticine 3 associated with the ability to kill sensitive cells, experiments were performed to determine which

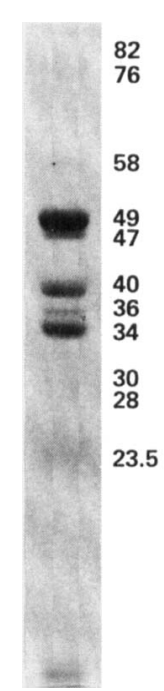

FIG. 2.-The protein components of purified proticine 3 separated on SDS-polyacrylamide gels. Numbers refer to the mol. wt $\left(\times 10^{3}\right)$ of the proteins. 
protein components were being synthesised at the time when biologically-active proticine particles were first detected within the cells.

No proticine activity was detected in the supernates of the non-induced GSYE cultures of $P$. mirabilis CW977 or the supernates of the sonicated cells and no proticine particles were seen by electronmicroscopy. The addition of mitomycin $\mathrm{C}$ did not affect the growth rate of $P$. mirabilis CW977 until 90 min after its addition, when the growth rate declined. After another $60 \mathrm{~min}$ the cells started to lyse (fig. 3). Proticine-3 activity was first detected in the supernates of sonicated mitomycin-induced culture samples $90 \mathrm{~min}$ after the addition of mitomycin C. The appearance of biologicallyactive proticine coincided with the appearance of "nail" forms. No proticine structural components were seen in samples taken before biological activity was detected.

The staining and fluorography of gels in which purified proticine was co-electrophoresed with ${ }^{3} \mathrm{H}$-labelled proteins formed during proticine production indicated which of the labelled proteins (fig. 4) were presumably proticine components. The proteins of mol. wt $82,76,49,47,34,30,28$ and $23.5 \times 10^{3}$ found in purified proticine were synthesised from the start of the induction period. The synthesis of proteins of mol. wt $82,76,49$ and $47 \times 10^{3}$ continued throughout the experiment but the synthesis of those of mol. wt $34,30,28$ and $23.5 \times 10^{3}$ ceased after c. $105 \mathrm{~min}$.

The synthesis of other proteins, with molecular weights identical to those found in

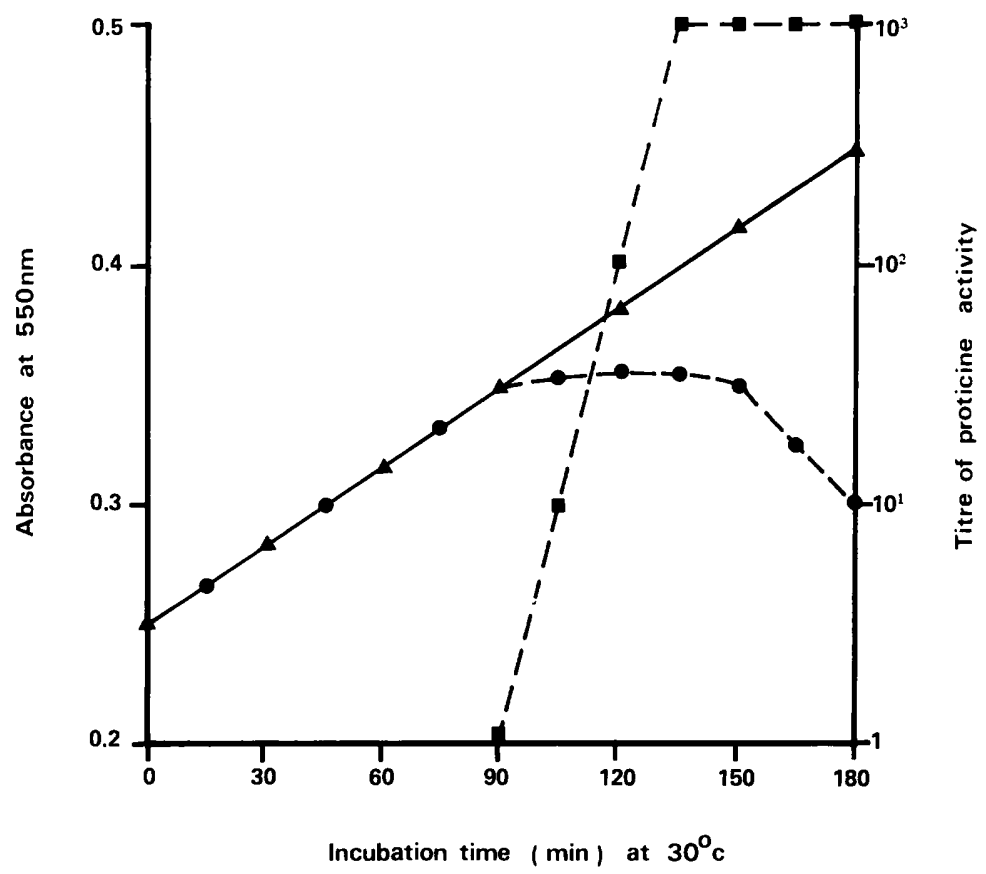

FIG. 3.-The effect of mitomycin $\mathrm{C}$ on growth and induction of proticine-3 production by $P$. mirabilis

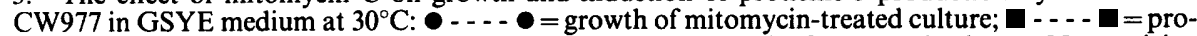
ticine production by mitomycin-treated culture; $\Delta-\Delta=$ growth of untreated culture. No proticine activity was detected in sonicates of untreated cells or cells treated with mitomycin for periods of $<90$ min. Mitomycin $\mathrm{C}$ added at Time 0. 


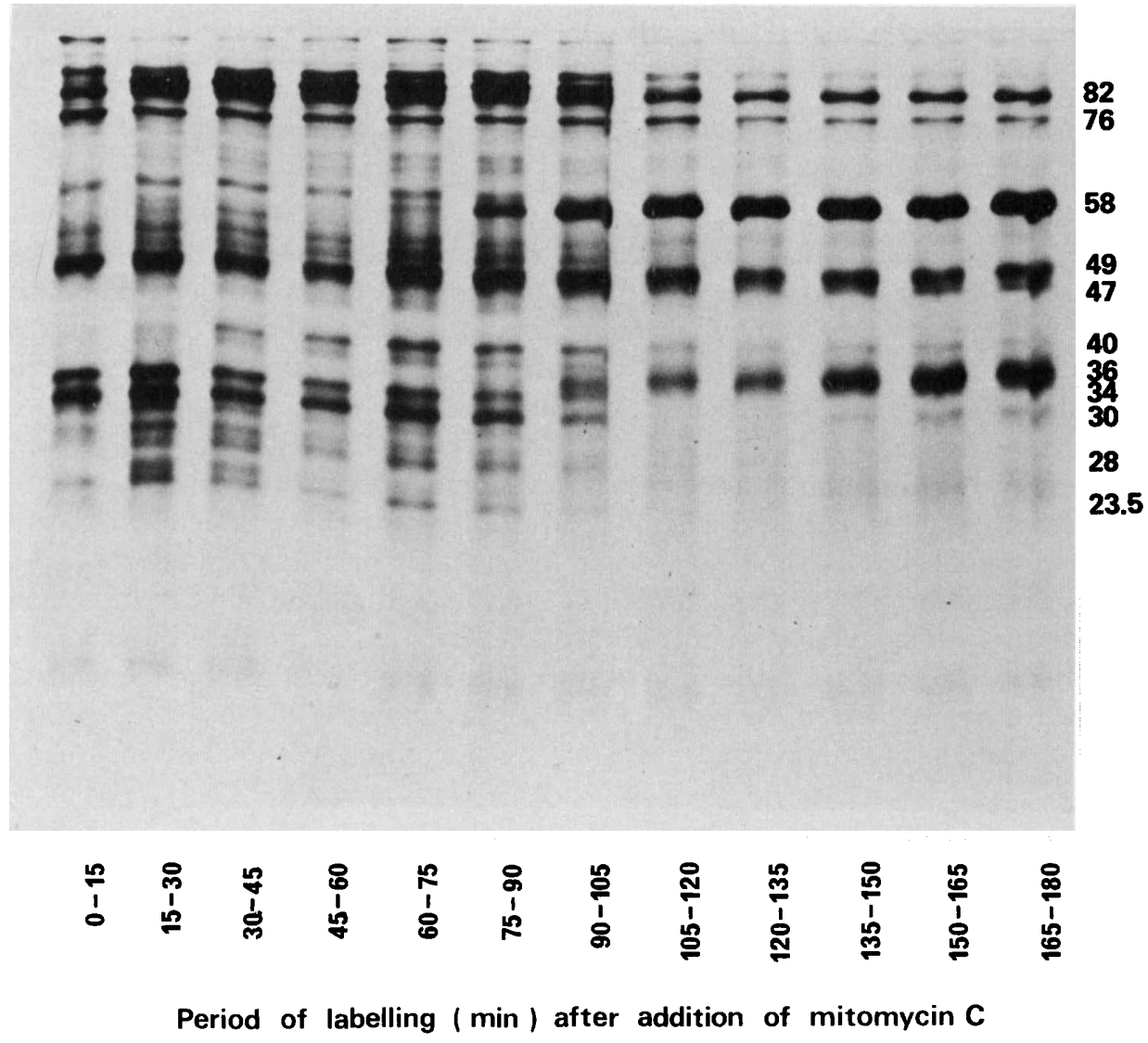

FIG. 4.-Fluorograph of the ${ }^{3} \mathrm{H}$ leucine-labelled proteins produced by $P$. mirabilis $\mathrm{CW} 977$ growing at $30^{\circ} \mathrm{C}$ in minimal medium and induced to produce proticine 3 by addition of mitomycin $\mathrm{C}$ at time $0 \mathrm{~min}$. Culture samples were labelled for $15 \mathrm{~min}$ every $15 \mathrm{~min}$ (from left to right) throughout a $3 \mathrm{~h}$ period. Numbers on the right refer to the mol. wt. $\left(\times 10^{3}\right)$ of the proteins. The start of the synthesis of the $58 \times 10^{3}-\mathrm{mol}$. wt protein (lane 6 ) coincided with the first detection of biologically-active proticine within the cells.

purified proticine, was delayed. The protein of mol. wt $40 \times 10^{3}$ appeared after $30 \mathrm{~min}$, the $58 \times 10^{3}-\mathrm{mol}$. wt protein after $90 \mathrm{~min}$ and the $36 \times 10^{3}$-mol. wt protein $105 \mathrm{~min}$ after the start of induction. The rate of synthesis of the 58 and $36 \times 10^{3}-\mathrm{mol}$. wt proteins increased with time, the $58 \times 10^{3}$-mol. wt protein becoming the most intensely labelled component of the culture. Early in the induction process, cells formed in large amounts an $86 \times 10^{3}$-mol. wt protein that was not a component of proticine. The cessation of its synthesis coincided with the appearance of the 58 and $36 \times 10^{3}-\mathrm{mol}$. wt proteins. Pulse-chase experiments revealed that the 58 and $36 \times 10^{3}$-mol. wt proteins were not formed by post-translational cleavage of the $86 \times 10^{3}-\mathrm{mol}$. wt protein.

All the structural components of proticine 3 except the 58 and $36 \times 10^{3}-\mathrm{mol}$. wt proteins appeared to be formed before biological activity could be detected. The presence and titre of biologically-active proticine 3 coincided with the synthesis of the $58 \times 10^{3}$-mol. wt protein. The synthesis of the $36 \times 10^{3}-\mathrm{mol}$. wt proticine component appeared to match the time course of cell lysis. 


\section{Discussion}

There is unequivocal evidence that the ability to produce certain bacteriocins is associated with bacterial virulence (Smith, 1974; Smith and Huggins, 1976). Cells carrying the Col V plasmid have an enhanced ability to adhere to intestinal epithelial cells (Clancy and Savage, 1981). In some instances the bacteriocin may have a pathogenic role by acting synergistically with endotoxin and by depressing macrophage activity (Ozanne, Mathieu and Baril, 1977). The strong association between proticine-3 production and upper-urinary-tract infections (Senior, 1979) suggested that there may be virulence genes associated with proticine- 3 production or that the proticine itself may have a pathogenic role. As a prelude to investigations of the pathogenic mechanisms, knowledge of the structure and composition of proticine 3 was necessary.

The proticine-3-purification scheme was chosen because I believed that the proticine existed naturally as a very large molecule; it diffused very poorly in agar and had been concentrated from liquid preparations by centrifugation. The purified end-product had considerable biological activity and a spectrum of activity indistinguishable from crude native proticine 3; activity was associated with structures that resembled T-even bacteriophage tails. No phage heads or complete phage particles were seen. Other workers (Taubeneck, 1963; Coetzee, de Klerk and Coetzee, 1968; Al-Jumaili, 1976) have found bacteriocin activity from Proteus strains to be associated with phage tail-like structures similar in morphology and dimensions to those of proticine 3. Although tail-like fibres, base plates and pins were not found with $P$. vulgaris bacteriocins (Coetzee et al., 1968) they appear to be present in proticine 3 and have been found in other bacteriocins from $P$. mirabilis (Al-Jumaili, 1976). These structures are important for attachment to specific receptor sites on the cell surface before contraction of the "nail" form to the "rocket" form. Biological activity is thought to be associated only with the "nail" form of the particulate bacteriocins (Coetzee et al., 1968; Higerd, Baechler and Berk, 1969). Higerd et al. (1969) reported that the conversion reaction of "nails" to "rockets" is reversible for pyocines although the conversion of a "rocket" back to a "nail" did not restore biological activity; it appeared that the lethal activity was lost in the initial change of a "nail" into a "rocket" form.

In these experiments, the "nail" form of proticine 3 was an unstable structure and some converted to the "rocket" form during purification and storage. The variation between different purified proticine-3 preparations in the proportion of some of the protein components possibly could be due to variation in the proportion of "nails" to "rockets" in the final purified preparations although this has not been investigated.

The $58 \times 10^{3}-\mathrm{mol}$. wt protein was a variable proticine 3 component. Fluorography showed that when proticine 3 was newly synthesized a $58 \times 10^{3}-\mathrm{mol}$. wt protein was the major labelled component in the induced culture whereas after purification of the proticine on sucrose gradients this was no longer the case. It is probable that some of the $58 \times 10^{3}-\mathrm{mol}$. wt protein was lost because of the prolonged purification procedure and the instability of the "nail" form. An alternative purification scheme by ammonium sulphate precipitation of cleared culture lysates followed by ion-exchange chromatography, without centrifugation, showed a $58 \times 10^{3}-\mathrm{mol}$. wt protein to be the major component of the proticine particle (unpublished results). Thus the change 
from the unstable, active "nail" form to the stable, presumably inactive "rocket" form may involve the loss of the $58 \times 10^{3}$-mol. wt protein.

The component of proticine 3 most likely to be associated with the killing action of the particle is the $58 \times 10^{3}-\mathrm{mol}$. wt protein because it was the only protein component for which synthesis coincided with the biological activity of proticine 3. An alternative or additional role for the $58 \times 10^{3}$-mol. wt protein is in the correct assembly of all the previously-synthesised protein components into the biologically-active "nail" form for "nails" (or "rockets") were not detected within the cell until the $58 \times 10^{3}$-mol. wt protein was synthesised.

If the $58 \times 10^{3}-\mathrm{mol}$. wt protein is the lethal factor of proticine 3 and the protein lost when an active "nail" converts to an inactive "rocket", it is attractive to consider that it might be located within the core. Evidence supporting this suggestion comes from the observation that no empty cores were seen in the active "nail" form (possibly because they were "full") although empty cores could be seen in the "rocket" form even through the thicker contracted outer sheath.

Proticine 3 is distinct from other bacteriocins in its spectrum of activity (Senior, 1977). It is very similar in morphology and structure to other Proteus bacteriocins. Its possible role, therefore, as a virulence factor in urinary-tract infections, if not due to association with other genetic determinants, must arise from either the distinct action of the lethal factor or the specificity of the tail fibres for receptors present on renal epithelial tissue rendering it susceptible to the action of the proticine- 3 lethal protein. An alternative explanation is that proticine-3-producing strains are virulent because of lysogenic conversion by a defective phage genome. These matters are being investigated. Already it is known that if such a conversion to virulence takes place, it is unlikely to involve adhesive mechanisms (Adegbola, Old and Senior, 1983).

\section{REFERENCES}

Adegbola, R. A., Old, D. C. AND Senior, B. W. 1983. The adhesins and fimbriae of Proteus mirabilis strains associated with high and low affinity for the urinary tract. Journal of Medical Microbiology, (in press).

AL-Jumaili, I. J. 1976. Physical properties and the fine structure of Proteocines. Zentralblatt für Bakteriologie, Parasitenkunde, Infektionskrankheiten und Hygiene, I. Abt., Orig., 235, 421-432.

BONNER, W. M. AND LASKEY, R. A. 1974. A film detection method for tritium-labelled proteins and nucleic acids in polyacrylamide gels. European Journal of Biochemistry, 46, 83-88.

BraUde, A. I., ShapIRo, A. P. AND SIEMIENSKI, J. 1959. Hematogenous pyelonephritis in rats. iii. Relationship of bacterial species to the pathogenesis of acute pyelonephritis. Journal of Bacteriology, 77, 270-280.

BRAUDE, A. I. AND SIEMIENSKI, J. 1960. Role of bacterial urease in experimental pyelonephritis. Journal of Bacteriology, 80, 171-179.

Clancy, J. and Savage, D. C. 1981. Another colicin V phenotype: In vitro adhesion of Escherichia coli to mouse intestinal epithelium. Infection and Immunity, 32, 343-352.

COETZEe, H. L., De KleRK, H. C. AND COETZEe, J. N. 1968. Bacteriophage tail-like particles associated with intra-species killing of Proteus vulgaris. Journal of General Virology, 2, 29-36.

Eudy, W. W., Burrous, S. E. AND Sigler, F. W. 1971. Renal lysozyme levels in animals developing "sterile pyelonephritis". Infection and Immunity, 4, 269-273.

Fairley, K. F., Carson, N. E., Gutch, R. C., Leighton, P., Grounds, A. D., Laird, E. C., McCallum, P. H. G., Sleeman, R. L. AND O'Keefe, C. M. 1971. Site of infection in acute urinary tract infection in general practice. Lancet, 2, 615-618. 
Grabow, W. O. K. AND Smit, J. A. 1967. Methionine synthesis in Proteus mirabilis. Journal of General Microbiology, 46, 47-57.

Griffith, D. P., MuShER, D. M. AND CAMPBell, J. W. 1973. Inhibition of bacterial urease. Investigative Urology, 11, 234-238.

Higerd, T. B., BAEChleR, C. A. AND BeRK, R. S. 1969. Morphological studies on relaxed and contracted forms of purified pyocin particles. Journal of Bacteriology, 98, 1378-1389.

LAEMMLI, U. K. 1970. Cleavage of structural proteins during the assembly of the head of bacteriophage T4. Nature, London, 227, 680-685.

LASKEY, R. A. AND Mills, A. D. 1975 . Quantitative film detection of ${ }^{3} \mathrm{H}$ and ${ }^{14} \mathrm{C}$ in polyacrylamide gels by fluorography. European Journal of Biochemistry, 56, 335-341.

Musher, D. M., Griffith, D. P., Yawn, D. AND Rossen, R. D. 1975. Role of urease in pyelonephritis resulting from urinary tract infection with Proteus. Journal of Infectious Diseases, 131, 177-181.

Ozanne, G., Mathieu, L. G. And Baril, J. P. 1977. Production of colicin V in vitro and in vivo and observations on its effects in experimental animals. Infection and Immunity, 17, 497-503.

SENIOR, B. W. 1977. Typing of Proteus strains by proticine production and sensitivity. Journal of Medical Microbiology, 10, 7-17.

SenioR, B. W. 1979. The special affinity of particular types of Proteus mirabilis for the urinary tract. Journal of Medical Microbiology, 12, 1-8.

Senior, B. W., Bradford, N. C. AND Simpson, D. S. 1980. The ureases of Proteus strains in relation to virulence for the urinary tract. Journal of Medical Microbiology, 13, 507-512.

SilverblatT, F. J. 1974. Host-parasite interaction in the rat renal pelvis. A possible role for pili in the pathogenesis of pyelonephritis. Journal of Experimental Medicine, 140, 1696-1711.

SMITH, H. Williams. 1974. A search for transmissible pathogenic characters in invasive strains of Escherichia coli: the discovery of a plasmid-controlled toxin and a plasmid-controlled lethal character closely associated, or identical, with colicine V. Journal of General Microbiology, 83, 95-111.

SMITH, H. Williams AND HugGins, M. B. 1976. Further observations on the association of the colicine $\mathrm{V}$ plasmid of Escherichia coli with pathogenicity and with survival in the alimentary tract. Journal of General Microbiology, 92, 335-350.

TAUBENECK, U. 1963. Uber die Produktion biologische aktiver Phagen-Schwänze durch einen defekt lysogenen Proteus mirabilis-Stamm. Zeitschrift für Naturforschung, 18b, 989-991. 